\title{
GALICIA AS AN INTERTEXT: THE CONCEPT OF THE FRONTIER IN THE NOVEL “THE END OF DAYS” BY JENNY ERPENBECK
}

\section{Ievgeniia V. Voloshchuk}

European University Viadrina. Frankfurt (Oder), Germany. Email: voloshchuk[at]europa-uni.de

\begin{abstract}
The article analyses the model of the cultural space underlying the image of Galicia in the novel The End of Days by Jenny Erpenbeck. The research is focused on the intertextual elements used to create this image, their functions and the range of their interactions with the concept of the frontier. The myth of Galicia, the works of Karl Emil Franzos, Joseph Roth, Johann Wolfgang Goethe as well as Old Testament stories and psalms are considered as the main sources of intertextuality. Based on the analysis it can be inferred that the novel uses the intertextual elements not only for the wide cultural contextualization of the image of Galicia but also for the subversion of both the myth of Galicia and the literary pretexts from which these elements are borrowed.
\end{abstract}

\section{Keywords}

frontier; Galicia; pretext; intertext; motif; myth of Galicia; family history; cultural geography; Eastern European Jewry

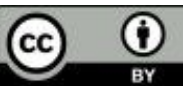

This work is licensed under a Creative Commons «Attribution» 4.0 International License 


\title{
ГАЛИЦИЯ КАК ИНТЕРТЕКСТ: КОНСТРУКТ ПОГРАНИЧЬЯ В РОМАНЕ «ХВАЛИ ДЕНЬ К ВЕЧЕРУ ДЖЕННИ ЭРПЕНБЕК
}

\section{Волощук Евгения Валентиновна}

Европейский университет Виадрина. Франкфурт-на-Одере, Германия.

Email: voloshchuk[at]europa-uni.de

\begin{abstract}
Аннотация
В статье анализируется модель культурного пространства, положенная в основу образа Галиции в романе «Хвали день к вечеру» Дженни Эрпенбек. Исследовательский фокус направлен на используемые для создания этого образа интертекстуальные элементы, их функции и спектр их взаимодействий с конструктом пограничья. При этом в качестве основных источников интертекстуальности рассматриваются литературный миф Галиции, произведения Карла Эмиля Францоза, Йозефа Рота, Иоганна Вольфганга Гете, а также ветхозаветные сюжеты и псалмы. Из анализа резюмируется вывод о том, что в романе интертекстуальные элементы используются не только для широкой культурной контекстуализации образа Галиции, но и для субверсии, направленной как на миф Галиции, так и на литературные претексты, из которых они заимствуются.
\end{abstract}

\section{Ключевые слова}

пограничье; Галиция; претекст; интертекст; мотив; миф Галиции; семейная история; культурная география; восточноевропейское еврейство

Это произведение доступно по пицензии Creative Commons «Attribution» («Атрибуция») 4.0 Всемирная 
Журнал Фронтирных Исследований. 2021. No 2 | ISSN: 2500-0225

Пограничные исследования в современной европейской литературе | Doi: https://doi.org/10.46539/jfs.v6i2.304

\section{ВВЕДЕНИЕ}

С момента культурного «переоткрытия» Галиции, стартовавшего в немецкоязычном пространстве ${ }^{1}$ вместе с публикацией посвященной ей книги Мартина Поллака (Pollack, 2001), галицкая тема не выходит из литературной моды. Наиболее яркими свидетельствами тому являются многочисленные литературные путешествия в Галицию. По мнению известного австрийского слависта Алоиза Вольдана, возник даже особый литературный жанр таких путешествий со специфическим комплексом мотивов и топосов (Woldan, 2015). Одновременно растет корпус фикциональных текстов, в разных формах и вариациях разрабатывающих галицкую тему. К их числу относится и высоко оцененный рецензентами (Auffermann, 2018; Böttiger, 2012) роман «Хвали день к вечеру» (“Aller Tage Abend”, 2012) известной современной немецкой писательницы Дженни Эрпенбек (род. 1967). Галицкой теме в нем посвящена только одна, первая глава, рассказывающая о семейной предыстории и начале жизненного пути протагонистки. Путь этот пролегает через мировые войны, падение старых империй и появление новых государств, смертельные угрозы коричневого и красного тоталитаризма, разрушение Берлинской стены и установление нового европейского порядка. Неудивительно, что захудалый пограничный галицкий городок Броды, в котором протагонистка появляется на свет, почти теряется из виду на фоне обширной географии ее дальнейших странствий, охватывающих постгабсбургскую Вену, сталинскую Москву, лагерь для политических узников на крайнем Севере, Уфу и Узбекистан военных лет, Берлин времен ГДР и, наконец, объединенную Германию. И тем не менее, галицкая глава в романе отнюдь не эпизодическая: она задает тон дальнейшему сюжету и проявляет ту экзистенциальную и социальную матрицу, которая впоследствии будет воспроизводиться в разных исторических декорациях. С учетом этого в данной статье ставится задача проанализировать модель культурного пространства, положенную писательницей в основу образа Галиции и связанного с ним этапа семейной истории. При этом исследовательский фокус направлен на используемые для создания этого образа интертекстуальные элементы, их функции, а также спектр их взаимодействий с конструктом пограничья.

1 В немецком пространстве это открытие произошло на несколько десятилетий позже по сравнению с Польшей, где аналогичный процесс начался еще в 1960-е гг. (Jakubów, 2015). 


\section{ОТ ГАБСБУРГСКОЙ ГАЛИЦИИ ДО ПАДЕНИЯ БЕРЛИНСКОЙ СТЕНЫ}

Обращение к топосу Галиции в романе «Хвали день к вечеру» объясняется не только литературной модой. Дело в том, что в основу жизненной истории своей протагонистки Дженни Эрпенбек положила биографию своей бабушки - немецкой писательницы, актрисы, режиссера, кабаретистки и журналистки Хедды Циннер (1904-1995) ${ }^{1}$, принадлежавшей когорте признанных мастеров соцреалистического пера в бывшей ГДР. По одной из версий, Хедда Циннер родилась в галицком городе Лемберге (ныне Львове), что и нашло отражение в романе «Хвали день к вечеру» наряду с другими событиями ее жизни - политической эмиграцией в рамках левого движения в СССР 1930-х гг., эвакуацией во время Второй мировой войны и др. С этой точки зрения, «галицкая» глава встраивается в фактуальную биографию, якобы реконструируемую в романе.

Вместе с тем, Эрпенбек пользуется приемом, подрывающим реалистичность этой биографии. Историю своей героини она выстраивает в виде цепочки следующих друг за другом пяти вариантов биографии, каждый из которых заканчивается ее смертью, а затем получает продолжение на новом сюжетном отрезке - вплоть до «окончательной» смерти, настигающей ее в 90-летнем возрасте. Благодаря этому жизнеописание протагонистки приобретает нарочитый фикциональный характер, приближаясь то ли к конъюнктивному «как бы»повествованию, то ли к компьютерной игре с ее «запасом» жизней, то ли, наконец, к литературно-издательскому трюку «продолжение следует». Процесс фикционализации затрагивает и галицкое пространство: оно демонстративно описывается как образ, сотканный из узнаваемых литературных мотивов.

В каждом варианте биографии протагонистка предстает в другом образе, другой фазе своей жизни и другом интерьере, репрезентирующем определенный этап «большой» истории. Так, в первой главе главная героиня - новорожденная, увидевшая свет в габсбургской Галиции в начале XX в. и задохнувшаяся в собственной колыбели в возрасте восьми месяцев. В следующей главе это завершение судьбы «переигрывается»: девочку в колыбели спасает от смерти горсть снега, брошенная ей в лицо. Теперь она предстает в образе семнадцатилетней девушки в Вене, куда ее еще в детстве привезли родители, перебравшиеся сюда из Галиции в поисках лучшей жизни. Однако реальность развенчивает эти иллюзии: отец с трудом отыскивает здесь отнюдь не

1 На этот эмпирический материал указывают многие рецензенты романа Эрпенбек (см., например, Kutzner, 2013) 


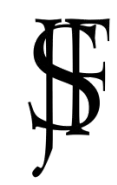

Журнал Фронтирных Исследований. 2021. No 2 | ISSN: 2500-0225

Пограничные исследования в современной европейской литературе | Doi: https://doi.org/10.46539/jfs.v6i2.304

хлебное место мелкого сотрудника метеорологической службы; мать на его скудное жалованье едва сводит концы с концами, а сама героиня добровольно уходит из жизни вследствие экзистенциального кризиса, вызванного несчастной любовью, эмоциональным истощением, идентичностными разрывами и глубоким разочарованием в мире, исковерканным Первой мировой войной. В третьем варианте биографии выясняется, что вместо того, чтобы наложить на себя руки, героиня занялась литературным творчеством и вступила в коммунистическую партию. То и другое позволило ей - к тому времени уже 36-летней коммунистке - эмигрировать в сталинскую Россию. Спустя несколько лет ее вслед за мужем приговаривают к сроку в ГУЛАГе, где она умирает в нечеловеческих условиях. В четвертой версии биографии ей, в отличие от мужа, удается избежать гибели в лагерях и относительно благополучно пережить Вторую мировую войну в эвакуации. Вместе с сыном, родившимся в новых любовных отношениях, она по окончании войны переезжает в Восточную Германию, делает здесь громкую литературную и общественную карьеру и умирает на 60-м году вследствие неудачного падения с лестницы в собственном доме. Наконец, в пятой и последней версии, она доживает до падения Берлинской стены, впадает в деменцию, и её списывают со счетов эксзвезда ГДРовской литературы. В конечном, счёте она которая умирает в 90-летнем возрасте в доме престарелых. Именно здесь читатель впервые узнает ее фамилию - Гофманн.

Таким образом, эта биография, начинающаяся в 1902 г. и заканчивающаяся в 1992 г., охватывает почти все XX столетие. Наряду с этим, она представляет собой летопись странствий порожденного этим столетием типажа - человека, оторванного от своих корней, гонимого ветром истории и пытающегося укорениться в той реальности, где под разноцветными флагами обещанного лучшего мира снова и снова перекраивается политическая карта и тем самым снова и снова аннулируются прежние ориентиры и ценности, снова и снова гибнут надежды на полноценную жизнь.

В ходе повествования галицкое прошлое из истории госпожи Гофманн и ее семьи стирается. Лишь в финале романа оно неожиданно оживает в одной незначительной детали: среди архивных безделушек, которые героиня перебирает в доме престарелых, оказываются золотые пуговицы с мундира ее отца, который тот носил в годы службы в габсбургской Галиции. 


\section{ВОЗВРАЩЕНИЕ МИФА?}

Со своей галицкой главой Эрпенбек подключается к богатой литературной традиции, отсылающей прежде всего к мифу Галиции. К его центральным мотивам Дитлинд Хюхткер относит (аграрную) бедность, отсталость, мультикультурность, мультиконфессиональность и полиэтничность. Последнюю репрезентирует констелляция, включающая прежде всего евреев, поляков, австрийцев и «рутенов» (как навали в Австро-Венгрии православных и греко-католиков, в т. ч. украинцев) и другие этнические группы. Важное место в мифе Галиции занимают галицкие евреи: их жизнь в штетле и гетто, религиозные и культурные традиции, противоречия еврейской ассимиляции и взаимоотношений евреев с другими этническими группами и другие аспекты. Кроме того, миф тематизирует окраинное и пограничное расположение Галиции и ее географическую близость к Российской империи. После Первой мировой войны к указанному тематико-эстетическому комплексу добавилась ностальгия по «затонувшей» габсбургской Галиции, изображаемой как некий идиллический топос, а также реквиемная нотка по поводу падения Дунайской монархии (Hüchtker, 2002, pp. 81-82).

Многие из указанных элементов мифа Галиции нашли отражение в галицкой главе романа «Хвали день к вечеру». Местом действия писательница делает габсбургскую Галицию, чья принадлежность Дунайской монархии подчеркивается беглыми и немногочисленными, но запоминающимися упоминаниями о проезде императора через местную железнодорожную станцию, Галицкой железной дороге имени Карла Людвига, связывавшую восточную провинцию с центром империи или должности «К. и к.-чиновника» ${ }^{1}$. Модель мультиэтнического пограничья представлена приграничными Бродами, разделенными на гетто, в котором живут предки протагонистки, и не еврейскую часть, куда со временем переезжает ее бабушка. Среди действующих лиц галицкой главы - евреи, австрийцы, поляки, а также «дезертиры» неопределенной этнической принадлежности, очевидно, нелегально попавшие сюда из соседней Российской империи. Присущий мифу Галиции топос «вавилонского» смешения народов наглядно иллюстрируется в галицкой главе браком австрийца и еврейки, в котором рождается протагонистка. При этом основной упор делается на еврейской теме - описании семейной истории, представленной тремя поколениями предков протагонистки,

1 “k. und k.” или "k. u. k." - сокращение обозначения «императорский и королевский», принятого в Дунайской монархии после заключения Австро-венгерского соглашения 1867 г. 
внутрисемейных отношений, традиций и обрядов. Отдельные вкрапления идиша: "Maideleh" (Erpenbeck, 2014, p. 12), "Saj mojchl un fal mir meine trep nit arunter" (p. 14), "Voz iz mit dir? Mameleh, voz iz mit dir?" (p. 60) и др., - подчеркивают экзотический колорит восточноевропейского еврейства, использовавшего идиш в повседневном общении. А вместе с тем - языковое и культурное разнообразие Галиции.

Кроме того, в центр галицкой главы выдвинута характерная для мифа Галиции тема распада старого порядка. Она репрезентируется, главным образом, семьей протагонистки. После смерти восьмимесячной девочки отец тайком бежит в Америку, а мать становится проституткой. Тем временем умирают еврейские прадед и прабабка протагонистки - последние ревностные блюстители традиций предков. Разорение семейного гнезда и внутренний кризис, в который - каждый по-своему - погружаются родители умершей девочки, символически знаменуют собой не только закат еврейского патриархального мира, но и разрушение традиционной семьи и ее ценностей.

Связь с мифом Галиции усиливается за счет литературных влияний двух крупнейших «летописцев» галицкого пограничья, чье творчество существенным образом способствовало формированию этого мифа: Карла Эмиля Францоза (1848-1904), считающегося одним из «первооткрывателей» данного региона в немецкоязычной литературе второй половины ХIX в., и Йозефа Рота (1894-1939), снискавшего славу «Гомера затонувшей габсбургской Галиции» (ШмідтДенглер, 2007, с. 42).

\section{ПО СЛЕДАМ ФРАНЦОЗА И РОТА}

На поверхности лежит, в частности, параллель между галицкой главой и рассказом Францоза «Шейлок из Барнова». В нем представлена история богатого и влиятельного барновского еврея, который отрекся от дочери, сбежавшей с тайным возлюбленным-гусаром. Навсегда похоронив ее в своем сердце, он не отступил от своего проклятья даже в тот день, когда его единственная дочь, измученная пережитыми унижениями и мытарствами, вернулась и, умоляя о прощении, умерла на пороге дома. Похожую историю читатель находит и в галицкой главе романа «Хвали день к вечеру». В ней прадед протагонистки справляет траурный обряд по внучке из-за ее брака с австрийцем. Так же, как красавица Эстер из рассказа Францоза, она оказывается брошенной на произвол судьбы. Но если ее литературная предшественница раскаивается, возвращается домой и умирает как трагическая жертва жестоких обстоятельств, то героиня Эрпенбек добровольно выбирает профессию проститутки и беспово- 
ротно движется по пути моральной деградации. И если Францоз разоблачает убийственную жестокость патриархального еврейского мира, негативным воплощением которого у него служит образ отца Эстер - барновского «Шейлока», то Эрпенбек диагностирует бессилие еврейской традиции перед новой эпохой и девальвацию семейных отношений - как по межгенерационной вертикали, так и по гендерной «горизонтали».

Обращает на себя внимание и то, что наряду с типичными предметами еврейских обрядов, вроде меноры или лавки для шивы (траурного обряда) Эрпенбек включает в описание быта еврейской семьи полное собрание сочинений Гете. Эта деталь дважды пересекается с галицким текстом Францоза. Во-первых, в том же «Шейлоке из Барнова» огромную роль в эмансипации героини, ее дальнейшем разрыве с отцом и еврейской традицией играют светские книги, которыми она против воли отца тайком зачитывается. Примечательно, что объектом ее читательской страсти становится смешанная библиотека, в которой книги немецких классиков Гейне или Клопштока дополняются особо популярными в то время развлекательными сочинениями Луизы Мюльбах или Поля де Кока. А, во-вторых, гетевское собрание сочинений в галицкой главе Эрпенбек отсылает к германофильским настроениям Францоза, в частности - к его идее облагораживающего воздействия духа немецкого Просвещения на габсбургские восточные провинции и - далее - на «Полуазию» ${ }^{1}$. Вспоминается, например, его рассказ «Шиллер в Барнове», который завершается, по сути, пропагандистской картиной: польский монах, украинский крестьянин и еврей-студент благоговейно склоняются над объединяющих и просветляющих их томом шиллеровских стихов. Аналогичная символическая идея сближения культур в романе Эрпенбек считывается и с гетевского издания, подаренного еврейскому деду протагонистки по случаю завершения образования. Ведь, как минимум, такой подарок предполагает, что его обладатель является поклонником веймарского классика и либо уже может прочесть гетевские сочинения в оригинале, либо надеется сделать это в будущем. В еврейской семье, проживающей в гетто на окраине Галиции, появление такого издания само по себе свидетельствует о пересечении еврейско-немецкой языковой и культурной границы. Однако, как показывают события галицкой главы, гетевское издание становится наглядным доказатель-

1 К показательным в этом отношении текстам Францоза относятся, в частности, «Шиллер в Барнове» (“Schiller in Barnow”), «Жертва» (“Ein Opfer”), «Из Вены в Черновцы» (“Von Wien nach Czernowitz”), «Между Днестром и Быстрицей» (“Zwischen Dniester und Bistrizza”), «Культурный праздник» (“Ein Culturfest”) и др. 


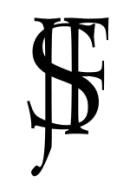

Журнал Фронтирных Исследований. 2021. No 2 | ISSN: 2500-0225

Пограничные исследования в современной европейской литературе | Doi: https://doi.org/10.46539/jfs.v6i2.304

ством как раз непроницаемости и трагической конфликтности этой границы.

Другим значимым источником интертекстуальных элементов образа Галиции в романе Эрпенбек выступает творчество Йозефа Рота. На значимость ротовского влияния прямо указывает уже тот факт, что главным местом действия в галицкой главе становятся Броды родной город Рота, прославившийся, по словам Дмитрия Затонского, в качестве его «литературной родины» ${ }^{1}$.

Первое же предложение романа, начинающееся узнаваемой цитатой из Книги Иова: «Господь дал, Господь взял» ${ }^{2}$ (Erpenbeck, 2014, p. 11) и через нее отсылающее к образу библейского Иова, навеивает ассоциации с ротовским романом «Иов», в котором этот образ используется как парадигматическое обобщение фигуры главного героя и судьбы восточноевропейского еврейства в начале XX века в целом. В дальнейшем эта ассоциация закрепляется другими перекличками между обоими текстами. Так, изображаемая Эрпенбек история внучки ортодоксального еврея, которая сначала выходит замуж за австрийца, а потом пополняет ряды профессиональных проституток, напоминает жизнеописание дочери ротовского Менделя Зингера - красавицы Мирьям, которая сначала пытается спастись от своих дурных наклонностей в браке с иноверцем-американцем, а после того, как муж ее бросает, становится жертвой собственной нимфомании. Впрочем, не только ротовский «Иов» возникает на горизонте галицкой главы романа Эрпенбек, но и его знаменитое эссе «Евреи в странствиях», а также другие его «еврейские» тексты, благодаря которым он приобрел репутацию литературного адвоката восточноевропейского еврейства. Одной из самых узнаваемых ротовских деталей у Эрпенбек является упоминание о «медно-рыжем» цвете волос, унаследованном протагонисткой от ее еврейских предков по женской линии: Рот считал такой цвет волос отличительной чертой галицких евреев (Roth, 1990d, p. 283) и наделял им персонажей собственных фикциональных и нефикциональных текстов.

Следуя ротовской модели пограничной мультинациональной Галиции, Эрпенбек описывает Броды как «последний бастион» ${ }^{3}$ (Й. Рот) Габсбургов на границе с Российской империей. Сведущий читатель найдет в ее романе знакомую по ротовским текстам пограничную корчму, в которой тайком перебравшиеся через границу

1 Исследователь замечает, что, Галиция была для Рота «желанной отчизной, которая способствовала воплощению его самых смелых мечтаний - человеческих и литературных, личных и даже общественных» (Затонський, 1998, с. 151).

2 Здесь и далее текст романа «Хвали день к вечеру» цитируется в моем переводе - Е.В.

3 Этот мотив у Рота подробно исследуется Марией Кланьской (Kłańska, 1990). 
русские дезертиры пьют «высокопроцентную» водку, а темные дельцы охотятся на неудачников, желающих попытать счастья в Америке. Как и в Галиции Рота, здесь тоже ощутимо присутствие границы между двумя империями. Однако у Эрпенбек она мифологизируется и трансформируется из политико-географического объекта в экзистенциально-поэтическую картину. Так, в сцене похорон восьмимесячной протагонистки ее мать думает о том, что небо над могилой дочери должно быть таким же огромным, как Альпы, которых никогда не видела, но воспринимает как знакомую часть «своей» географии. Тем самым маленький надгробный холмик в далекой провинции вписывается в пространство огромной Габсбурской империи. Вместе с тем, в сознании той же героини закрепляются мифологические представления о близости границы к России. Время от времени она вспоминает о том, как в детстве «она была убеждена в том, что мир плоский, как блин, и она - так же, как другие жители этого приграничного городка - заброшена крупинкой сахара на самый краешек этого блина. Когда ей случалось заблудиться на окраине города, ее охватывал страх, будто она слишком близко подошла к границе и внезапно упала за край [...] При этом горизонт, как она со временем узнала в школе, был ничем иным, как прямой линией, которая тянулась через всю Россию» (Erpenbeck, 2014, p. 37).

Образ затерянной на краю и/или падающей за край крупинки будет многократно повторяться в разных историко-биографических контекстах в дальнейшем повествовании - как некий архетип пограничной экзистенции, впечатанный в семейную историю.

Ротовские мотивы вплетены и в образ отца протагонистки. Австриец, прибывший из столицы в восточную провинцию на службу, он представляет собой фигуру, символизирующую одновременно и «маленького человека» Габсбургской империи, и ее верного служаку. В галицкой главе он предстает мелким чиновником ${ }^{1}$, обслуживающим Галицкую железную дорогу имени Карла Людвига. Помимо очевидной прагматичной цели, эта дорога имела еще и политическое значение в качестве «репрезентанта» имперского духа, соединявшего отдаленный приграничный уголок и сердце империи (Pollack 2001, p. 12). Собственную незначительную должность отец отождествляет со службой империи. А последнюю он, в свою очередь, возводит чуть ли не в главный элемент своей идентичности. Об этом свидетельствует его странный сантимент к мундирным золотым пуговицам с отчека-

1 В последующей, «венской», главе, в которой читатель встречается с отцом протагонистки в последний раз, он трудится в должности служащего столичной метеорологической службы, фиксирующего погодную турбулентность и стихийные бедствия в Вене периода Первой мировой войны. 


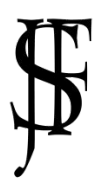

Журнал Фронтирных Исследований. 2021. No 2 | ISSN: 2500-0225

Пограничные исследования в современной европейской литературе | Doi: https://doi.org/10.46539/jfs.v6i2.304

ненными на них двуглавым орлом и габсбургской короной. И хотя такие пуговицы украшали униформу всех железнодорожных чиновников в Габсбургской империи, в жизни отца протагонистки, равно как и в ее семейной истории, они превращаются в своеобразный фетиш старого порядка и наглядное напоминание о былой принадлежности к империи. Так, в Америке, куда герой в галицкой главе эмигрирует после смерти восьмимесячной дочери и где он переживает своеобразное перерождение под новым именем в новой реальности, эти пуговицы становятся последним и единственным знаком его былой «австрийскости». А в следующей главе униформа железнодорожного чиновника с теми же имперскими пуговицами появляется в качестве особого атрибута: отец протагонистки, служащий венского метеорологического института, упорно носит ее в постгабсбургской Вене, тем самым манифестируя и анахроничную верность погибшей Габсбургской империи, и внутренний протест против новой эпохи, стершей его родную страну с лица земли:

«В январе 1919 г. на золотых пуговицах на отцовском мундире все еще было изображение двуглавого орла и короны кайзера, хотя "императорско-королевский” император ${ }^{1}$ уже два года как мертв, а венгерская половина орла давно улетела прочь. Однако мундир все еще греет, поэтому отец день за днем сидит в своем едва отапливаемом, но уже демократичном бюро в Венском метеорологическом институте, - сидит и пестует любовь ко всему императорскому и королевскому, а после службы идет в едва отапливаемое кафе «Виндобона», чтобы сыграть там две партии в шахматы с приятелем и коллегой, и тоже сидит там в мундире, да и дома не снимает мундир, так как дрова, которые мать вместе со старшей дочерью несколько раз в неделю приносит из Венского леса, - сырые и, попадая в кухонную печь, больше трещат, чем горят» (Erpenbeck, 2014, p.79).

После того, как золотые пуговицы переживут и крах империи, и смерть хозяина, и даже утилизацию его мундира, они будут бережно храниться протагонисткой до последних дней ее жизни.

В привязке образа отца протагонистки к имперскому контексту и идее «цивилизующей» роли Габсбурского дома содержатся имплицитные отсылки к ротовской апологетике Дунайской монархии и его галерее «верноподданных», сохраняющих верность империи даже после ее распада. Так же, как ротовские персонажи - Карл Йозеф Тротта в «Марше Радецкого» или Ансельм Эйбеншютц в «Фальшивом весе», - герой Эрпенбек отправляется в Галицию для прохождения службы и поддержания там имперского порядка. Так же, как для названных ротовских героев, галицкая провинция с ее атмосферой

1 В оригинале с помощью этой тавтологии обыгрывается формулировка «к.и к.». 
причудливого упадка становится для него местом внутренней деградации и утраты самого себя. И даже в двух дальнейших сценариях развития его биографии - американском и венском - тоже просматриваются вариации ротовских историй. В американском варианте его тайное бегство в Америку и происходящие там деформации идентичности, вплоть до замены исконного австрийского имени «Йохан» американским именем «Джо», перекликаются с судьбой второго сына Менделя Зингера, - дезертировавшего из русской армии в Америку Шемарьи, который там становится Сэмом. А в венском варианте он пополняет ряды анахроничных почитателей рухнувшей империи, обреченно цепляющихся за ее девальвированные атрибуты (и здесь его симпатия к списанному мундиру с золотыми пуговицами сопоставима с фанатичным почтением ротовского графа Морстина к бюсту и короне умершего императора.

Широко используя ротовскую модель Галиции, Эрпенбек в то же время отклоняется от его установки на идеализацию последнего периода Габсбургской империи, который Стефан Цвейг ностальгически называл «золотым веком» Дунайской монархии. Воспетую Ротом «идиллию» габсбургской Галиции писательница поворачивает изнаночной стороной, на которой проявляются те проблематичные и конфиликтные процессы, которые скрываются за радужной картиной мирного соседства народов и в недалеком будущем изнутри взорвут, казалось бы, незыблемую многонациональную империю.

\section{НА ПЕРЕСЕЧЕНИИ ВЕТХОВАЗЕТНОГО И ГЕТЕВСКОГО ПРЕТЕКСТОВ}

Грозные симптомы латентного неблагополучия габсбургской Галиции проявляются в эпизоде еврейского погрома, который образует концептуальный центр галицкой главы. По времени он совпадает с молодостью дедушки и бабушки протагонистки, а также ранним детством ее матери. История о том, как во время погрома соседиполяки зарубили топором мужа на глазах жены, а жена, спасаясь от озверевших преследователей, упала с крыши и чудом избежала смерти, обнажает жуткую реальность, которая скрывается за фасадом Габсбургского мифа о мирном соседстве народов (Magris, 1996), населявших этот «большой дом со множеством дверей и окон» (Roth, 1990b, c. 675). Неслучайно главным погромщиком в галицкой главе оказывается давний знакомый бабушки протагонистки, поляк Андрей: 
«Они с мужем не успели закрыть ставни внизу, как в дом полетели первые камни. Муж попытался рассмотреть, кто бросает камни, и узнал Андрея. Андрей, - позвал он, - Андрей! Но Андрей не слышал, или делал вид, что не слышал, потому что он-то знал, кто жил в доме, который забрасывал камнями. Один из камней Андрея пролетел через оконную щель, на волосок разминулся с ее головой, ударился о застекленный книжный шкаф позади нее и попал в девятый том полного издания Гете в кожаном переплете, который ее муж получил от родителей в подарок к окончанию школы» (Erpenbeck, 2014, c.15).

Рассказ о внезапном перерождении соседа в погромщика дополняется беглым упоминанием о том, что в комнате, в которой молодая супружеская пара пытается забаррикадироваться от преследователей, были припасены (заранее!) доски как раз на случай подобных экстренных ситуаций. Эти доски самим своим присутствием сигнализируют о хрупкости и ненадежности мира между этническими группами в габсбургской Галиции. Еще более убедительно об этом свидетельствует царапина, оставленная камнем на томе из гетевского собрания сочинений. Она служит наглядным знаком краха и идеи счастливого многонационального соседства, и веры в объединяющую силу культуры, и силы кровавых межэтнических столкновений, сметающих на своем пути прекрасные, но беспомощные перед ними идеалы немецкого Просвещения. Более того, эта царапина ставит том Гете в один ряд с жертвами погрома - хозяином дома и его женой. В итоге Гете, символизирующий вершину немецкой культуры, оказывается таким же гонимым и ненавидимым «чужаком», как и обитатели еврейского гетто.

Сцена погрома, вписанная в перспективу воспоминаний бабушки протагонистки, тоже насыщается интертекстуальными элементами. Правда, их источниками служат уже не «галицкие» тексты немецкоязычной литературы, а ветхозаветный и гетевский претексты.

Первой в этой части повествования появляется цитата из гетевского стихотворения «Морская тишина». Она резюмирует уже упомянутый эпизод с камнем, повредившим гетевский том:

«Ветр не веет благодатный

Тишина, как смерть, страшна,

На пространстве необъятном

Не поднимется волна» (Гете, 1968, с. 364) ${ }^{1}$.

Изображаемое в этих строчках обманчивое и опасное затишье на море (“Todesstille fürchterlich”) можно интерпретировать двояким

1 Цит. в переводе К.С. Аксакова. 
образом. В рамках сцены погрома оно прочитывается как намек на краткую передышку перед новым актом погрома, в котором, как следует из дальнейшего рассказа, погромщики перейдут от обычного разбоя к убийству. А в рамках создаваемого в романе Эрпенбек образа габсбургской Галиции - как метафора иллюзорной идилличности и реальной взрывоопасности многонационального соседства. И в обоих контекстах гетевская цитата усиливает эмоциональное напряжение описываемого эпизода до жуткого ощущения нависшей смертельной опасности.

Далее цитруются строки из 38 псалма Давида: «Услышь, Господи, молитву мою и внемли воплю моему; не будь безмолвен к слезам моим, ибо странник я у Тебя и пришлец, как и все отцы мои. Отступи от меня, чтобы я мог подкрепиться, прежде нежели отойду и не будет меня» (Псалтирь, 1990, с. 586). В контексте псалма эта цитата резюмирует мотивы суетности и скоротечности человеческого существования, вопрошаний о смертном часе, обращения к Богу с надеждой на заступничество и мольбой о том, чтобы не быть преданным «на поругание безумцу» (Псалтирь, 1990, с. 586). В контексте сцены погрома данная цитата совпадает с последним моментом коварного затишья, когда преследуемые муж и жена, скрывшись за тонкой, прикрытой хлипким засовом дверью, прислушиваются к последним шагам погромщиков, уже добравшихся до этой же двери. Строки псалма выражают их отчаянную надежду на помощь Господа. Но она вдребезги разбивается о дальнейший ход событий, вследствие которого супружеская пара действительно оказывается преданной «на поругание безумцам». Примечательно, что в немецком варианте в процитированных строчках псалма фигурируют слова «гость» (“Gast”, ср. с русским аналогом «странник») и «чужак» ("Fremdling”, ср. с русским аналогом «пришелец»). В сцене погрома библейская экзистенциальная семантика этих образов вытесняется этнокультурной смысловой доминантой, проявляющей угрожаемое положение еврейской диаспоры в Галиции (и - шире - в Восточной Европе). Евреи здесь - «гости» и «чужаки», которые в любой момент, как демонстрирует погром, могут стать изгнанниками и врагами. Заметим, что появляющееся в цитате упоминание предков («как все мои отцы») придает положению гостя-чужака парадигматическое значение. Последнее находит подтверждение в биографии протагонистки: на разных этапах своей своего жизненного пути госпожа Гофманн снова и снова попадает в положение «гостя-чужака» (даже в главе об успешной писательской карьере в ГДР за портретом 


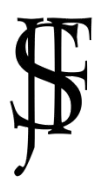

Журнал Фронтирных Исследований. 2021. No 2 | ISSN: 2500-0225

Пограничные исследования в современной европейской литературе | Doi: https://doi.org/10.46539/jfs.v6i2.304

уважаемой писательницы-коммунистки скрывается женщина с изломанной судьбой и замалчиваемым прошлым).

Третий интертекстуальный элемент включается в кульминацию погрома. В тот момент, когда выбравшаяся на крышу жена пытается вытащить за руку к себе мужа, а погромщики внизу тянут его за другую руку к себе, в повествование вводится парафраз библейской истории о Лоте. Первое его предложение: «Лот не хочет выдавать ангелов, которые у него в гостях» (Erpenbeck, 2014, p. 21), подхватывает мотив «гостя-чужака», подчеркивая его сакральный статус. Одновременно оно имплицитно провоцирует отождествление погромщиковсоседей с погрязшими в грехах жителями Содома и Гоморры. Дальнейший рассказ построен как развертывание параллели между Лотом, которому угрожает ярость его сограждан, и дедушкой протагонистки, который пытается вырваться из рук погромщиков. Важным маркером здесь становится цитата из финального абзаца псалма 39: «Боже мой! Не замедли» (р. 21), заостряющая противоречие между реальностью и Священным Писанием - между Лотом, который успевает спастись, и дедушкой протагонистки, который не успевает ускользнуть от своих мучителей. Последующее описание погрома построено как развернутое противопоставление библейской ситуации и переживаемой реальности. Так, спасение Лота изображается следующим образом:

«Лот стоит на пороге, народ хватает его и хочет вытащить из дому, чтобы наказать за закон гостеприимства, который он защищает, чтобы Лота избить, оплевать, ободрать, растоптать; но ангелы ангельскими руками из дому хватают его за руку; у них есть сила поразить людей на улице слепотой, втащить Лота в дом и закрыть дверь между ним и людьми; люди на улице больше не могут видеть друг друга и входную дверь в дом Лота, они ощупывают руками стену и вынуждены отступить» (р. 21).

Непосредственно к этому описанию привязывается картина гибели дедушки протагонистки:

«У нее [его жены - бабушки протагонистки - Е.В.] нет силы ангелов, ей не удается вытащить мужа наверх; крепко держа мужа за руку, она просит о пощаде Андрея, которого знает с пеленок и просит о пощаде мужчин, которых не знает, в том числе - мужчину с топором; но пока она крепко держит за руку мужа, мужчины, которых она не знает, и Андрей, которого она знает с пеленок, сначала поносят ее мужа, затем его бьют, щадят и, наконец, разрубают топором у нее на глазах. Сначала она держит за руку мужа, затем она держит за руку кусок его тела, затем не остается ничего живого, что она могла бы вытащить наверх к себе. И вот уже она - еврейская вдова, которая держит за руку смерть» (р. 21-22). 
Гибель хозяина дома описывается здесь как негативный вариант истории библейского Лота. К хозяину дома, в отличие от Лота, помощь свыше не приходит, а его жене, в отличие от ставшей соляным столпом Лотовой жены, удается спастись, но, как показывает дальнейший сюжет, ценой ампутации собственного прошлого. Так в сцене погрома проявляется трагическое расхождение между библейским текстом, постулирующим победу чуда над силами зла, и переживаемой реальностью, в которой силы зла исключают самую возможность чуда. Это расхождение между Библией и жизнью, как можно заключить из последующих действий бабушки протагонистки, становится причиной ее разрыва и с еврейским гетто, и с верой предков.

Все последующие события семейной истории в галицкой главе объясняются через призму этой травмы - погрома и вызванного им внутреннего кризиса героини.

Именно эта травма побуждает бабушку сначала перебраться из еврейского гетто в нееврейский квартал, где она чувствует себя в большей безопасности, затем долгое время скрывать от дочери правду о гибели ее отца за легендой о том, что тот бросил семью и живет где-нибудь во Франции или Америке, а затем, вопреки запретам традиции, выдать рыжеволосую дочь-красавицу замуж за «гоя» без доходов, серьезного социального положения и особых личных достоинств. Но этот брак, заключенный с обеих сторон из соображений выгоды, оказывается дефектным для них прежде всего вследствие своей этнической неоднородности. Еврейское происхождение жены становится неустранимым препятствием даже для самой скромной карьеры австрийского чиновника. А жизнь с «гоем» ставит молодую еврейку в положение аутсайдера не только в ее семье, но и в гетто. Изначально проблематичный и рискованный, этот брак распадается после смерти восьмимесячной дочери. Вскоре после похорон австрийский чиновник тайком бежит от бед и невзгод в Америку, где от его австрийскости остаются лишь пуговицы с двуглавым орлом. А предательство бежавшего в Америку мужа и разочарование в семейных ценностях подталкивают мать протагонистки к проституции, ради чего она перебирается из Бродов в Лемберг, где, по словам рассказчицы, уже никто не знает, «кто держал ее за руку, когда она в одиннадцать месяцев училась ходить, и никто не знает, что поляки виновны в том, что она не помнит отца, и также мало кто знает, что она все еще может назубок рассказать гетевского “Бога и баядеру"». В результате личность героини редуцируется на тело, в котором для оказания любовных услуг используются «руки, рот и другие отверстия» (р. 63). А о былой ее принадлежности к галицким евреям напо- 
минают лишь медно-рыжие волосы и оскорбительное обращение «ты, еврейская свинья» (р. 56), которое она порой слышит от своих клиентов. И даже ставшее семейной реликвией гетевское собрание сочинений редуцируется теперь до одной-единственной цитаты из «Бога и баядеры», констатирующей принятую героиней роль падшей женщины: «Раскаянье грешных любимо богами, / Заблудших детей огневыми руками / Благие возносят к чертогам своим» (Гете, 1797).

\section{ПОСЛЕ ГАЛИЦИИ}

Галицкая глава становится своеобразным претекстом для второго варианта биографии госпожи Гофманн, разворачивающегося в Вене 1919 г. Многие «галицкие» мотивы получают здесь дальнейшее развитие.

Так, в качестве одной из характерных примет Вены «после Габсбургов» Эрпенбек изображает бесстыдный антисемитизм, проявившийся в трагической форме еще в Бродах XIX века. Не в последнюю очередь он, как следует из повествования, был вызван в Вене как раз потоком галицких евреев, которых Первая мировая война и погромы вынудили бросить свои дома и искать прибежище в имперской столице. Однако Вена встретила нищих беженцев «с Востока» той же взрывоопасной смесью ненависти и презрения, которая в те дни поджигала их дома в Галиции. В то время, когда на венских рынках специально для новоприбывших галицких евреев выставлялись таблички с надписью «Трогать товары пальцами строжайше запрещено!» (Erpenbeck, p. 81), а на каждом углу прибывших евреев клеймили ругательствами «пожар, саранча, пиявки, чума или медведи, лисы, змеи, клещи и вши» (р. 81), по покоренной поляками Галиции катилась волна еврейских погромов. Лаконичное описание погрома в постгабсбургском Лебмерге вызывает в памяти картину погрома в Бродах, пережитого бабушкой протагонистки в молодости. В этом описании польские легионеры в послевоенном Лемберге предстают исторической модификацией тех соседей-поляков, которые в XIX в. обрушились на еврейское гетто в Бродах:

«Когда недавно поляки в Лемберге праздновали на центральной площади победу над украинцами, в двух улицах от них был подожжен еврейский квартал. Праздновали три ночи. Еврейских детей, которые пытались бежать, польские легионеры бросали в горящие дома, а в это время за выставленным кордоном кто-то играл на губной гармошке» (р. 120).

Параллель между антисемитскими настроениями в Вене и Лемберге высвечивает не только похожие или даже общие процессы 
на территориях затонувшей Дунайской монархии, а и различия между ними. Если в постгабсбургской Вене юдофобия еще ограничивается вербальными проявлениями, то в польском Лемберге она уже имеет характер садистского насилия, апробированного некогда в гасбсбургских Бродах (а в недалеком будущем - поставленного на индустриальную основу в нацистских лагерях уничтожения). Отсюда следует, что бывшая провинция империи на один исторический шаг опережает бывшую имперскую столицу по части радикализации насильственных практик, варваризации общественного сознания и нарастания нетерпимости, - иначе говоря, тех процессов, которые определяли ход европейской истории в первой половине $\mathrm{XX}$ в.. Именно в провинции конфоликт разных национализмов с мультинациональным и мультикультурным наследием Габсбургской империи достигает наибольшей силы; именно тут проступает контуры будущего Холокоста, и именно тут распахивается бездна того исторического безумия, которое станет трагической эмблемой столетия мировых войн, революций и тоталитарных режимов.

И все же бывшая имперская провинция опережает бывшую имперскую столицу только на один шаг. Вена на руинах империи это город, который по степени запустения и одичания мало чем отличается от затерянных на окраине Бродов конца XIX в.:

«В парках Вены летом трава по колено: на свободных участках выращивают морковку, картошку и свеклу; природа возвышается над Веной, стирает город, но это никого не беспокоит; уже давно не хватает жизни для того, чтобы поправлять и обрезать жизнь. Ты можешь, как мальчишка, / Сбивающий репьи,/ Крушить дубы и скальь (курсив автора - Е.В.) ${ }^{1}$. Аренбергерплатц ${ }^{2}$ летом почти ничем не отличается от лугов вокруг Бродов, находящихся на границе, вот только она [мать протагонистки - Е.В.] повзрослела и имеет другие заботы, чем ломать стебли орешника и мять траву, идя напрямик через поле, как делала это тогда, когда боялась пропустить край блина. Они не для того искали прибежище в Вене, чтобы тут помереть с голоду. Но ведь невозможно предвидеть мгновенье, в которое выяснится, что желание неосуществимо» (рp. 81-82).

Преемственная связь между послевоенной Веной и довоенными Бродами подчеркивается здесь не только мотивами запустения и сахарной крупинки на краю блина, но и гетевской цитатой, напоминающей о том самом собрании сочинений веймарского классика, которое стало немым свидетелем погрома в Бродах. Кроме того, приведенные здесь строки из гетевского «Прометея» перекликаются

1 Фрагмент стихотворения «Прометей» Й. В. Гете, цит. в переводе В. Левика (Гете, n.d.).

2 Аренбергпарк - парк, расположенный в третьем районе Вены, Данненбергплаце.. 
с цитатой из гетевского «Бога и баядеры», приведенной в рассказе о том, как мать протагонистки стала проституткой. Обе цитаты указывают на фигуры аутсайдеров, взбунтовавшихся против высшего закона. Сверх того, посредством этих цитат выстраивается параллель между описанием ставшей проституткой матери протагонистки в галицкой главе и картиной погрязшей в запустении имперской столицы в венской главе.

Новое развитие в венском контексте получает и мотив двуглавого орла, символизирующего Габсбургскую империю. Переехав в 1908 г. в имперскую столицы, семья протагонистки поселилась в доме с двуглавым орлом у входной лестницы. Увидев его впервые, мать главной героини подумала, что под крылом имперской птицы ее родные найдут защиту и счастье. Но в одичавшей Вене «после Габсбургов» в этой скульптуре проступает другой образ:

«Наверное, орел внизу лестницы на самом деле был скорее стервятником и много лет ожидал их конца; она же в любом случае сопротивляется этому и не позволяет ему превратить ее семью в добычу, но для этого ей нужно напрячь все силы» (р. 81).

Кроме того, в венской биографии обозначен новый поворот темы конфронтации с еврейской идентичностью. Чтобы скрыть свое еврейское происхождение, мать протагонистки не рассказывает дочерям о еврейских предках и изолирует их от бабушки, внешность которой выдает ее принадлежность к восточноевропейскому еврейству ${ }^{1}$. Наблюдая за мутациями, которые происходят с его женой в Вене, муж приходит к выводу о том, что «она замкнулась в своем мозаичном происхождении, как в клетке, и теперь до крови бьется о прутья» (р. 96). Этот конфликт передается и юной протагонистке. Когда та впервые задумывается о своих еврейских корнях, вопрос о том, почему от нее их скрывали и почему она сама тоже должна их скрывать, становится одной из причин ее добровольного ухода из жизни. Картина Венского кладбища, которой Эрпенбек заканчивает вторую версию биографии, сопровождается примечательным комментарием: всего за полторы минуты городской трамвай покрывает расстояние между христианской частью Венского кладбища, на котором расположена могила юной протагонистки, и четвертыми, еврейскими, воротами, за которыми обретает вечный покой ее бабушка. Более того: в заснеженном ландшафорте стираются любые

1 В свою очередь, бабушка соглашается жить на другом конце Вены, чтобы отвести от семьи подозрения в еврейских корнях. Она смиряется с тем, что дочь довольствуется случайными встречами с ней на базаре, а внучкам, воспитанным в христианской вере, запрещается ее посещать. 
различия между обоими кладбищами, - таков главный итог второй части семейной истории. Вместе с тем, снег на могилах бабушки и внучки ассоциативно соединяет их смерть в Вене с погромом в Бродах, когда по еврейскому гетто летали похожие на снежинки перья из выпотрошенных перин и подушек. Гибель главной героини, а затем последовавшая за ней смерть отца, до последнего дыхания оставшегося верноподданным Габсбурской империи, и смерть бабушки, так не отрекшейся от еврейской идентичности, подводит символическую итоговую черту под постгабсбургским этапом семейной истории.

\section{ВЫВОДЫ}

В галицкой главе романа «Хвали день к вечеру»
Дженни Эрпенбек Галиция инсценируется как фактический и символический исходный пункт сюжетного движения. В ней намечены главные мотивы жизнеописания главной героини: утрата родины деформации идентичностей, обусловленные историческими и социальными потрясениями, стигматизация в качестве преследуемого «чужого» / «врага» (в том числе - и на почве антисемитстких предрассудков), кризис старой гуманистической системы ценностей, наконец, - конфронтация с прошлым, которая, выражается, среди прочего, в разломе семейной истории, радикальном разрыве с опытом предыдущих поколений и замалчивании исторических травм.

Например, конфронтация с прошлым, описываемая в галицкой главе как следствие погрома, последовательно проводится через каждый новый отрезок жизненного пути госпожи Гофманн. Так, в Вене героиня восстает сначала против матери, замалчивающей свое еврейское происхождение, а затем против мелкобуржуазной среды, которой принадлежит ее семья. В сталинском СССР ее прежнее австро-венгерское гражданство, мелкобуржуазное происхождение и годы жизни на капиталистическом Западе оказываются серьезным основаниями для того, чтобы быть зачисленной в список «врагов народа». В социалистической Германии ей ради успешной литературной карьеры приходится молчать о пережитом опыте сталинских репрессий. А после падения Берлинской стены она сама становится объектом замалчивания - как и другие интеллектуалы, прежде обслуживавшие свергнутую коммунистическую идеологию. Таким же образом из главы в главу переходит идея взаимосвязи между распадом семьи и сменой системой ценностей - вплоть до последней главы, в которой сын, вопреки сомнениям совести, но зато в духе нового прагматизма отдает ее в дом престарелых, где она обречена 


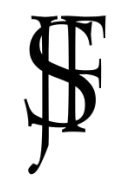

Журнал Фронтирных Исследований. 2021. No 2 | ISSN: 2500-0225

Пограничные исследования в современной европейской литературе | Doi: https://doi.org/10.46539/jfs.v6i2.304

на одиночество, отчуждение и мелочную конфронтацию с выживающими из ума соседками.

Таким образом, в контексте романа Галиция выступает пространством, в котором закладывается «матрица» дальнейшего повествования, определяющая как непосредственно биографическую сюжетную линию, так и символическое измерение странствий главной героини. В рамках этого измерения с жизнеописания протагонистки считывается панорама XX века, фиксирующая важнейшие тектонические сдвиги и катастрофы европейской истории. И основополагающее значение здесь имеет сцена погрома в галицких Бродах.

На уровне семейной истории она маркирует первый слом, совпадающий с эпохальным поворотом восточноевропейской еврейской диаспоры к модернизации и ассимиляции на рубеже XIX-XX столетий. В этот контекст вписывается не только сам по себе разрыв бабушки протагонистки с гетто и еврейскими традициями, но и его последствия, пронизывающие всю личную и семейную историю главной героини: распад традиционной модели семейных отношений и внутренняя конфронтация с собственной (еврейской) идентичностью.

На символическом уровне эта сцена прочитывается как многослойная прелюдия к восточноевропейской истории первой половины XIX в. ${ }^{1}$. Ее можно интерпретировать как послание о разрушении многонационального соседства вследствие рецидива архаичного варварства. В этом случае она приобретает значение концептуального пролога к европейской истории XX в., искалеченной аналогичными, но возведенными в высшую степень эксцессами насилия. Наряду с этим, в сцене погрома можно увидеть интродукцию к истории преследований европейского еврейства, которая достигла своего апогея в Холокосте. Наконец, если сфокусироваться на габсбургской Галиции, репрезентирующей на правах метонимии (Kłańska, 1989, p. 148) многонациональную Дунайскую монархию, то сцена погрома прочитывается как метафорическое вступление к распаду Габсбургской империи, обусловленному, по тому же Роту, ростом националистического движения и межэтнической вражды внутри многонационального государства.

Воспринимая Австро-Венгрию через призму Габсбургского мифа о процветании и идиллическом единстве народов, которые ее населяли, Рот приписывал ей значение образцового государства. Последнее, по его мнению, эффективно содействовало продуктивному

1 В этой связи Марек Якубов справедливо замечает: «В известному романе «Хвали день к вечеру» истоки европейской истории восходят к галицкой провинции - городку Броды» (Jakubów, 2015, p. 56). 
взаимодействию многих культур, поддерживало мультинациональное равновесие и, по словам одного из ротовских персонажей, в те времена, «когда человек еще был важнее его нации», было родиной для всех этнических групп, живших на его обширных территориях (Roth, 1990c, p. 922). Соответственно, его гибель, обусловленная, по мнению писателя, безответственным заигрыванием власти с националистичнскими настроениями подданных, ознаменовала собой крах самого проекта многонационального государства и начало тримуфального шествия демонов национализма. Интересно, что эта трактовка европейской истории первой трети XX в. получила полную поддержку со стороны жителя одной из бывших провинций Габсбургской империи, известного венгерского писателя и лауреата Нобелевской премии, Ирме Кертеша. В одно из интервью он, в частности, сказал:

«Йозеф Рот, пожалуй, яснее других писателей понял, что значила гибель Австро-Венгерской монархии: именно тут лежал корень национализма источник трупного яда. Были основаны малые национальные государства, чей национализм казался оправданным. Но, в конце концов, это привело к нацизму и Второй мировой войне» (Plath, 2007).

Этот прогноз Рота-политического мыслителя развивает в своем романе Дженни Эрпенбек. Более того, она вытесняет этим прогнозом ту идиллическую картину габсбургской Галиции, которую Ротхудожних настойчиво создавал в своих романах и рассказах. Из последней (пятой) версии биографии протагонистки Эрпенбек читатель узнает о том, что ее бабушка, мать и младшая сестра в 1940-е годы были депортированы в Восточную Европу и погибли в нацистстких лагерях. Так история соединяет в одну цепочку габсбургские Броды, постгабсбургскую Вену и нацистский Аушвиц. В этом контексте насильственное «возвращение» членов семьи в Восточную Европу прочитывается как трагическая перверсия возвращения к истокам семейной истории, в том числе - к погрому в Бродах.

Как показывает проведенное исследование, в образе Галиции, созданном в галицкой главе романа «Хвали день к вечеру» Дженни Эрпенбек, накладываются друг на друга три топоса. Первый - топос утраченной родины семейной истории, репрезентирующий важное «место памяти» Восточной Европы. Второй - топос пограничья, который в данном случае конкретизируется положением пограничной земли между двумя большими империями, фиксирующей границу между Западом и Востоком Европы, многократно пересекаемую протагонисткой романа в течение ее долгих жизненных странствий. 


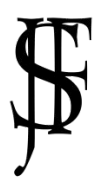

Журнал Фронтирных Исследований. 2021. No 2 | ISSN: 2500-0225

Пограничные исследования в современной европейской литературе | Doi: https://doi.org/10.46539/jfs.v6i2.304

Наконец, третьим базовым компонентом является топос Галиции. При этом в целом и в многочисленных деталях писательница опирается на ту модель культурного пространства, которая была выработана мифом Галиции. Тем не менее, речь идет не о механическом перенесении этой модели, а о ее литературной стилизации. Потому что Эрпенбек не столько воспроизводит этот миф, сколько его переконструирует и «олитературивает», расставляя в нем специфические акценты, оспаривая некоторые его аспекты и в значительной степени форматируя его как многослойный интертекст.

Центральными источниками интертекста в галицкой главе (намного шире, кстати заметить, присутствующему в ней, чем в остальных частях книги) являются тексты Карла Эмиля Францоза и Йозефа Рота, относящихся к «создателями» галицкого мифа, Гете, символизирующего связующий и просвещающий дух немецкой культуры, а также библейские повествования и псалмы, репрезентирующие мировосприятие и культуру патриархального восточноевропейского еврейства. Использование этих элементов имеет разнонаправленный характер. С одной стороны, они служат историко-культурной контекстуализации и литературной стилизации мифа Галиции, в том числе - воссозданию этнического и культурного многообразия галицкого пограничья. А, с другой, с их помощью осуществляется определенная субверсия, направленная как на сам миф Галиции, так и на претексты, из которых они заимствуются. Благодаря этому в романе и возникает многогранный образ Галиции как интертекста, укорененного одновременно и в галицком мифе, и в современном галицком дискурсе.

\section{ПОСТСКРИПТУМ}

В конце романа появляется неожиданная интертекстуальная отсылка к его началу, которую можно интерпретировать как идею возвращения к истокам (семейной) истории. Здесь бывшая убежденная коммунистка и легенда ГДРовской литературы, а ныне старая дама с почти стертыми воспоминаниями ностальгически достает золотые пуговицы с отцовского мундира и объявляет себя верным майором «к. и к.»-армии, готовым отправиться в поход. Этот ироничный итог жизни героини и истории ХХ в. отмечает собой новый этап европейской истории, на котором будущее Европы оказывается вновь связанным с теми вызовами, перед которыми она стояла 100 лет назад. 


\section{Список литературы}

Auffermann, V. (2012). Eine Frau, was aus ihr wurde und was hätte sein können [A woman, what became of her and what could have been]. Retrieved from Deutschlandfunk Kultur website: https://www.deutschlandfunkkultur.de/eine-frau-was-aus-ihrwurde-und-was-haette-sein-koennen.950.de.html?dram:article_id=223 043

Böttiger, H. (2012, October 25). Eine Romanfigur mit fünf Leben [A novel character with five lives]. Die Zeit. Retrieved from https://www.zeit.de/2012/44/Jenny-Erpenbeck-AllerTage-Abend

Erpenbeck, J. (2014). Aller Tage Abend [The end of days]. München: Albrecht Knaus.

Hüchtker, D. (2002). Der "Mythos Galizien". Versuch einer Historisierung [The 'Myth of Galicia'. Attempt of historicization]. In M. Müller \& R. Petri (Eds.), Die Nationalisierung von Grenzen. Zur Konstruktion nationaler Identität in sprachlich gemischten Grenzregionen [The Nationalization of Borders. On the Construction of National Identity in Linguistically Mixed Border Regions] (pp. 81-107). Marburg: Herder-Institut.

Jakubów, M. (2015). Nach der Wiederentdeckung Galiziens [After the rediscovery of Galicia]. In M. Dubrowska \& A. Rutka (Eds.), Reise in die Tiefe der Zeit und des Traums. (Re-)Lektüren des ostmitteleuropäischen Raums aus österreichischer, deutscher, polnischer und ukrainischer Sicht [fourney into the Depths of Time and Traums. (Re-)Readings of the East Central European Space from Austrian, German, Polish and Ukrainian Perspectives.] (pp. 54-72). Lublin: Wydawnictwo KUL.

Kaszyński, St. (1996). Der jüdische Anteil der Literatur in und über Galizien [The Jewish part of the literature in and about Galicia]. In M. Gelber, H. O. Horch, \& S. P. Scheihel (Eds.), Von Franzos zu Canetti. Füdische Autoren aus Österreich. Neue Studien [From Franzos to Canetti. Jewish Authors from Austria. New Studies] (pp. 129-140). Tübingen: De Gruyter.

Kłańska, M. (1990). Die galizische Heimat im Werk Joseph Roths [The Galician Homeland in the Works of Joseph Roth]. In M. Kessler \& F. Hackert (Eds.), Foseph Roth. Interpretation-Kritik-Rezeption. Akten des internationalen, interdisziplinären Symposions 1989 [Joseph Roth. Interpretation-Criticism-Reception. Acts of the international, interdisciplinary symposium 1989] (pp. 143-157). Tübingen: Stauffenburg.

Kutzner, N. (2013). Jenny Erpenbeck: Aller Tage Abend [Jenny Erpenbeck: The end of days]. Retrieved from Glitzernde Wörter website: https://

glitzerndewoerter.wordpress.com/2013/06/25/jenny-erpenbeck-aller-tage-abend/

Magris, C. (1996). Der habsburgische Mythos in der modernen österreichischen Literatur [The Habsburg Myth in Modern Austrian Literature]. Turin: Paul Zsolnay.

Michaelis-König, A. (2018). Einleitung [Introduction]. In Auf den Ruinen der Imperien. Erzählte Grenzräume in der mittel- und osteuropäischen Literatur nach 1989 [On the Ruins of Empires. Narrated Border Spaces in Central and Eastern European Literature after 1989] (pp. 14-15). Berlin: Neofelis.

Plath, J. (2007). Stunde der Wahrheit. Gespräch mit dem Nobelpreisträger Imre Kertész: Über Europa und die Verteidigung seiner Werte [Moment of truth. Conversation with Nobel Prize winner Imre Kertész: On Europe and the defense of its values.]. Re- 
trieved from Neue Zürcher Zeitung website: https://www.nzz.ch/ stunde_der_wahrheit-1.524547

Pollack, M. (2001). Galizien. Eine Reise durch die verschwundene Welt Ostgaliziens und der Bukowina [Galicia. A journey through the disappeared world of Eastern Galicia and Bukovina.]. Frankfurt am Main: Insel.

Roth, J. (1990a). Der Leviathan [The Leviathan]. In Werke [Works]. Vol. 6. (pp. 515-544). Köln.

Roth, J. (1990b). Die Büste des Kaisers [The bust of the emperor]. In Werke [Works]. Vol. 5 (pp. 655-676). Köln: Kiepenheuer \& Witsch.

Roth, J. (1990c). Hiob [Job]. In Werke [Works]. Vol. 5 (pp. 1-136). Köln: Kiepenheuer \& Witsch.

Roth, J. (1990d). Reise durch Galizien [Journey through Galicia]. In Werke [Works]. Vol. 2 (pp. 281-292). Köln: Kiepenheuer \& Witsch.

Woldan, A. (2015). Zum deutschsprachigen Galiziendiskurs nach der Wende von 1989/1991 [On the German-language discourse on Galicia after the fall of communism in 1989/1991]. In Beiträge zu einer Galizienliteratur [Contributions to a Galicia Literature] (pp. 11-28). Frankfurt am Main: Peter Lang.

Zweig, St. (2010). Die Welt von Gestern. Erinnerungen eines Europäers [The World of Yesterday. Memories of a European]. Frankfurt am Main: Fischer.

Гёте, Й. В. (1797). Бог и баядера (А. К. Толстой, Пер.). Retrieved from Онлайн-библиотека русской литературы website: https://xn----7sbb5adknde1cb0dyd.xn--p1ai/ \%D0\%B3\%D0\%B5\%D1\%82\%D0\%B5-\%D0\%B1\%D0\%BE\%D0\%B3-\%D0\%B8\%D0\%B1\%D0\%B0\%D1\%8F\%D0\%B4\%D0\%B5\%D1\%80\%D0\%B0/

Гёте, Й. В. (1968). Морская тишина (Том 1; К. С. Аксаков, Пер.). Ленинград: Советский писатель.

Гёте, Й. В. (n.d.). Прометей (В. Левик, Пер.). Retrieved from Антология русской поэзии website: https://stihi-rus.ru/World/Gete/37.htm

Затонський, Д. (1998). Феномен австрійської літератури [Феномен австрийской литературы]. Вікно в Світ [Окно в Мир], (1), 76-82.

Псалтирь. (1990). В Библия. Книги Священного Писания Ветхого и Нового Завета. Канонические. В русском переводе с параллельными местами. Перепечатано с Синодального издания (сс. 569-639). Хельсинки: Avainsanoma.

Шмідт-Денглер, В. (2007). Експеримент Галичина-Йозеф Рот в історіях німецької та австрійської літератури [Эксперимент Галичина-Йозеф Рот в историях немецкой и австрийской литературы]. В Т. Гаврилів (Ред.), Факт як експеримент. Механізми бікиіоналізації дійсності у творах Йозефа Рота [Факт в качестве эксперимента. Механизмы фикционализации действительности в произведениях Йозефа Рота] (сс. 6-21). Львів: ВНТЛ-Класика. 


\section{References}

Auffermann, V. (2012). Eine Frau, was aus ihr wurde und was hätte sein können [A woman, what became of her and what could have been]. Retrieved from Deutschlandfunk Kultur website: https://www.deutschlandfunkkultur.de/eine-frau-was-aus-ihrwurde-und-was-haette-sein-koennen.950.de.html?dram:article_id=223 043 (In German).

Böttiger, H. (2012, October 25). Eine Romanfigur mit fünf Leben [A novel character with five lives]. Die Zeit. Retrieved from https://www.zeit.de/2012/44/Jenny-Erpenbeck-AllerTage-Abend (In German).

Erpenbeck, J. (2014). Aller Tage Abend [The end of days]. München: Albrecht Knaus. (In German).

Hüchtker, D. (2002). Der "Mythos Galizien". Versuch einer Historisierung [The "Myth of Galicia'. Attempt of historicization]. In M. Müller \& R. Petri (Eds.), Die Nationalisierung von Grenzen. Zur Konstruktion nationaler Identität in sprachlich gemischten Grenzregionen [The Nationalization of Borders. On the Construction of National Identity in Linguistically Mixed Border Regions] (pp. 81-107). Marburg: Herder-Institut. (In German).

Jakubów, M. (2015). Nach der Wiederentdeckung Galiziens [After the rediscovery of Galicia]. In M. Dubrowska \& A. Rutka (Eds.), Reise in die Tiefe der Zeit und des Traums. (Re-)Lektüren des ostmitteleuropäischen Raums aus österreichischer, deutscher, polnischer und ukrainischer Sicht [fourney into the Depths of Time and Traums. (Re-)Readings of the East Central European Space from Austrian, German, Polish and Ukrainian Perspectives.] (pp. 54-72). Lublin: Wydawnictwo KUL. (In German).

Kaszyński, St. (1996). Der jüdische Anteil der Literatur in und über Galizien [The Jewish part of the literature in and about Galicia]. In M. Gelber, H. O. Horch, \& S. P. Scheihel (Eds.), Von Franzos zu Canetti. Füdische Autoren aus Österreich. Neue Studien [From Franzos to Canetti. Jewish Authors from Austria. New Studies] (pp. 129-140). Tübingen: De Gruyter. (In German).

Kłańska, M. (1990). Die galizische Heimat im Werk Joseph Roths [The Galician Homeland in the Works of Joseph Roth]. In M. Kessler \& F. Hackert (Eds.), Joseph Roth. Interpretation-Kritik-Rezeption. Akten des internationalen, interdisziplinären Symposions 1989 [Joseph Roth. Interpretation-Criticism-Reception. Acts of the international, interdisciplinary symposium 1989] (pp. 143-157). Tübingen: Stauffenburg. (In German).

Kutzner, N. (2013). Jenny Erpenbeck: Aller Tage Abend [Jenny Erpenbeck: The end of days]. Retrieved from Glitzernde Wörter website: https:// glitzerndewoerter.wordpress.com/2013/06/25/jenny-erpenbeck-aller-tage-abend/ (In German).

Magris, C. (1996). Der habsburgische Mythos in der modernen österreichischen Literatur [The Habsburg Myth in Modern Austrian Literature]. Turin: Paul Zsolnay. (In German).

Michaelis-König, A. (2018). Einleitung [Introduction]. In Auf den Ruinen der Imperien. Erzählte Grenzräume in der mittel- und osteuropäischen Literatur nach 1989 [On the Ruins of Empires. Narrated Border Spaces in Central and Eastern European Literature after 1989] (pp. 14-15). Berlin: Neofelis. (In German). 
Plath, J. (2007). Stunde der Wahrheit. Gespräch mit dem Nobelpreisträger Imre Kertész: Über Europa und die Verteidigung seiner Werte [Moment of truth. Conversation with Nobel Prize winner Imre Kertész: On Europe and the defense of its values.]. Retrieved from Neue Zürcher Zeitung website: https://www.nzz.ch/ stunde_der_wahrheit-1.524547 (In German).

Pollack, M. (2001). Galizien. Eine Reise durch die verschwundene Welt Ostgaliziens und der Bukowina [Galicia. A journey through the disappeared world of Eastern Galicia and Bukovina.]. Frankfurt am Main: Insel. (In German).

Roth, J. (1990a). Der Leviathan [The Leviathan]. In Werke [Works]. Vol. 6. (pp. 515-544). Köln. (In German).

Roth, J. (1990b). Die Büste des Kaisers [The bust of the emperor]. In Werke [Works]. Vol. 5 (pp. 655-676). Köln: Kiepenheuer \& Witsch. (In German).

Roth, J. (1990c). Hiob [Job]. In Werke [Works]. Vol. 5 (pp. 1-136). Köln: Kiepenheuer \& Witsch. (In German).

Roth, J. (1990d). Reise durch Galizien [Journey through Galicia]. In Werke [Works]. Vol. 2 (pp. 281-292). Köln: Kiepenheuer \& Witsch. (In German).

Woldan, A. (2015). Zum deutschsprachigen Galiziendiskurs nach der Wende von 1989/1991 [On the German-language discourse on Galicia after the fall of communism in 1989/1991]. In Beiträge zu einer Galizienliteratur [Contributions to a Galicia Literature] (pp. 11-28). Frankfurt am Main: Peter Lang. (In German).

Zweig, St. (2010). Die Welt von Gestern. Erinnerungen eines Europäers [The World of Yesterday. Memories of a European]. Frankfurt am Main: Fischer.

Goethe, J. W. (1797). The God and the Bayadere (A. K. Tolstoy, Trans.). Retrieved from Online Library of Russian Literature website: https://xn----7sbb5adknde1cb0dyd.xn-p1ai/\%D0\%B3\%D0\%B5\%D1\%82\%D0\%B5-\%D0\%B1\%D0\%BE\%D0\%B3-\%D0\%B8\%D0\%B1\%D0\%B0\%D1\%8F\%D0\%B4\%D0\%B5\%D1\%80\%D0\%B0/ (In Russian).

Goethe, J. W. (1968). The Silence of the Sea (Vol; K. S. Aksakov, Trans.). Leningrad: Sovetskiy pisatel. (In Russian).

Goethe, J. W. (n.d.). Prometheus (V. Levik, Trans.). Retrieved from The Anthology of Russian Poetry website: https://stihi-rus.ru/World/Gete/37.htm (In Russian).

Satonskiy D. (1998). The Phenomenon of Austrian Literature. A Window on the World, (1), 76-82. (In Ukrainian).

Psalms. (1990). In The Bible. Books of the Old and New Testament Scriptures. Canonical. In Russian Translation with Parallel Passages. Reprinted from Synod Edition (pp. 569639). Helsinki: Avainsanoma. (In Russian).

Schmidt-Dengler, W. (2007). The Galicia Experiment - Joseph Roth in the Stories of German and Austrian Literature. In T. Havryliv (Ed.), Fact as Experiment. Mechanisms of Fictionalisation of Reality in the Works of Joseph Roth (pp. 6-21). Lviv: VNTL-Klasyka. (In Ukrainian). 